\title{
ІННОВАЦІЙНА РЕКОНСТРУКЦІЯ ПРОМИСЛОВОСТІ УКРАЇНИ В УМОВАХ СТАЛОГО РОЗВИТКУ
}

\section{ИННОВАЦИОННАЯ РЕКОНСТРУКЦИЯ ПРОМЫШЛЕННОСТИ УКРАИНЫ В УСЛОВИЯХ УСТОЙЧИВОГО РАЗВИТИЯ}

\section{THE INNOVATIVE RECONSTRUCTION OF INDUSTRY OF UKRAINE IN THE CONTECXT OF SUSTAINABLE DEVELOPMENT}

Економіка сталого розвитку формує новий погляд на стратегічне $і$ оперативне планування промислового розвитку держави. Складні економічні прочеси в Україні у другому десятилітті XXI століття переформатовують сприйняття промисловості та окремих видів економічної діяльності. У статті зроблена спроба визначити можливості для сталого розвитку переробної промисловості у таких сферах, як машинобудування, хімічна промисловість, енеговиробництво з метою збереження та розвитку потужностей регіоноутворюючих підприємств різних форм власності. В роботі наведено аналіз можливостей інновачійної реконструкиії добувної $i$ переробної промисловості Украӥни. Інновачійна реконструкиія передбачає иілеспрямовані капіталовкладення для відтворення виробничої діяльності на засадах інновачій економіки сталого розвитку. У дослідженні використані дані державного комітету статистики України $i$ підходи управління економіки сталого розвитку. В результаті виконання дослідження сформований перелік показників, які визначатимуть розвиток видів діяльності. Із застосуванням методології Форсайту сформовано матрицю вагомості напрямів диференціації $i$ диверсифікації переробної промисловості з визначенням можслиих інновацій та перспектив їх реалізації.

Ключові слова: економіка сталого розвитку, стратегія розвитку, методологія Форсайту, промислове підприємство, напрями диференщіації $i$ диверсифікащії промисловості.

Экономика устойчивого развития формирует новый взгляд на стратегическое и оперативное планирование промышленного развития государства. Сложные процессы экономики Украины во втором десятилетии ХХІ века переформатировали восприятие промышленности и отдельных видов экономической деятельности. В статье сделана попытка определить возможности для устойчивого развития перерабатывающей промышленности в таких сферах, как машиностроение, химическая промышленность, производство энергии с иелью сохранения и развития мощностей регионообразуюших предприятий разных форм собственности. В работе проведен анализ возможностей инновационной реконструкиии добывающей и перерабатывающей промышленности Украины. Инноваџионная реконструкиия предусматривает иелевые капиталовложения 
для воспроизводства производственной деятельности на основе инноваций экономики устойчивого развития. В работе использованы данные государственного комитета статистики Украинь и подходы управления экономики устойчивого развития. $B$ результате выполнения исследований сформирован перечень показателей для определения направления развития вида деятельности. Использование методологии Форсайта позволило сформировать матрииу весомости направлений диффреренциации и диверсификации перерабатывающей промышленности с определением возможных инноваций и путей их реализащии.

Ключевые слова: экономика устойчивого развития, стратегия развития, методология Форсайта, промышленное предприятие, направления дифференщиаџии и диверсификации промышленности.

Economics of sustainable development is creating a new perspective on strategic and operational planning for industrial development of the country. The article defines the opportunities for sustainable development of the processing industry in areas such as mechanical engineering, chemical industries and energy production. It will allow stabilizing the enterprises that are donors to developing certain of territories. The article analyses the possibilities of innovative reconstruction of mining and processing industries of Ukraine. The innovative reconstruction envisages targeted investments for the reproduction of industrial activity based on innovation for sustainable economic development. The research is based on data of the State Statistical Committee of Ukraine and the approaches of management for the economy of sustainable development. In the article generated the list of indicators to determine the direction development of activity. The use of the methodology of Foresight allowed generating the matrix of weightiness of trends of differentiation and diversification of the processing industry with the identification of innovation and possible ways of implementing them.

Keywords: economics of sustainable development, development strategy, methodology of Foresight, industrial enterprise, directions of differentiation and diversification of industry.

Вступ. Стратегії економічної і соціальної політики України з 2000 року прогнозували стійке зростання випуску промислової продукції, технологічне і технічне оновлення підприємств. Питаннями інноваційного розвитку промислових підприємств займалися О.А. Гавриш, Г.В. Карпінська, Г.О. Андрощук; удосконалення технологій управління підприємствами пропонували М.3. Згуровський, Я.І. Кологривов, О.І. Бабчинська, М.В. Макаренко; аналізом джерел інвестиційних ресурсів займалися С.В. Захарін, I. Цигіль; перспективи розвитку окремих видів економічної діяльності розглядали В.А. Студінський (паперова промисловість), Дейнеко Л.В. (харчова промисловість), В. В. Латодієнко (агропромисловий комплекс). Вітчизняні та світові науковці намагаються визначити сучасні методи передбачення перспектив розвитку промислового виробництва як запоруки економічного зростання та економічної безпеки суспільства.

У розвинених країнах від 75 до $85 \%$ приросту ВВП формується за рахунок нових або удосконалених технологій[1]. Автор [2] підкреслював, що основною проблемою керівники промислових підприємств на теренах СНД вважають відсутність оборотних засобів і намагаються вирішувати їі шляхом 
пошуку інвестицій або нових замовлень. Сьогодні підприємства України, на етапі формування стратегій розвитку і систем управління бізнес-процесами стикаються з питанням оновлення основних засобів в умовах обмежених оборотних коштів. Таким чином, різні підходи до формування конкурентоспроможності промислових підприємств у провідних країнах світу і в Україні формують кардинально відмінні позиції у світових рейтингах [1].

Визначення сучасних підходів до планування оновлення технікотехнологічної бази промислових підприємств залишається актуальним і не втрачає цінності для розвитку реальної економіки.

Постановка завдання. Й. Шумпетер визначив технологічні інновації як економічний засіб отримання прибутку на противагу теорії економічного зростання Дж. Фон Неймана [3]. Сучасна концепція сталого розвитку $[4,5]$ базується на оптимальному використанні обмеженого ресурсного забезпечення (у тому числі і технологій) для створення доходу із збереженням рівня сукупного капіталу, який створив цей дохід. Такий підхід формує завдання сталих інновацій як в економічному, так i в екологічному $\mathrm{i}$ соціальному вимірах.

При подальшому розвитку теорії і практики економіки сталого розвитку наукова думка зробила акцент на теорії i практиці Форсайту [6]. Ця методологія ефективна для прогнозування саме в періоди стрибкоподібних змін, практичної відсутності монотонних процесів, які характеризуються нелінійними функціональними залежностями. Основними ऑї етапами [6] зазначено формування структури показників, що характеризують сферу діяльності; створення карти системи, формування матриць, визначення зв'язків між елементами; визначення можливих інновацій та можливостей їх реалізації; побудова стратегій та сценаріїв розвитку сфери діяльності; реалізація розроблених заходів на практиці.

Таким чином, науковою проблемою сьогодні є визначення інноваційно актуальних напрямів оновлення, реконструкції i реставрації технікотехнологічної бази конкретних промислових підприємств (на прикладі таких видів економічної діяльності, як машинобудування, будівництво, енерговиробництво) 3 метою формування нових конкурентних сфер i покращення позиції держави у світових рейтингах.

В основу дослідження покладено гіпотезу, що стратегія розвитку держави входить у протиріччя 3 усвідомленими ризиками промисловців України. Фондоємна промисловість втрачає перспективи функціонування внаслідок відсутності інформаційного аналізу і систематизації.

Основними завданнями даної наукової роботи є формування структури показників сфери діяльності промислового підприємства, визначення актуальних можливих інновацій та перспектив їх реалізації. 
Методологія. Теоретичну основу дослідження становить методологія Форсайту. Методологічну основу становлять положення економіки сталого розвитку. Основними методами $є$ метод експериментальних досліджень, методи статистичного аналізу (попереднього групування даних, кореляційний аналіз), функціонально-вартісний аналіз, неформальні методи прогнозування та планування.

Результати дослідження. Відповідно до Стратегії «Україна - 2020» [7] Україна обрала шлях дерегуляції та розвитку підприємництва, реформ із захисту економічної конкуренції, реформ ринку капіталу, розвитку українського експорту. Пріоритетними напрямами розвитку визначено транспортну i телекомунікаційну інфраструктури, розвиток енергетики, сільського господарства та рибальства, житлово-комунальне господарство Інноваційні програми i космічна галузь розглядаються як фактори національної гордості [7].

Таким чином, такі види економічної діяльності як добувна промисловість та розроблення кар'єрів, переробна промисловість (у тому числі поліграфія, виробництво машин і устаткування),будівництво можуть реалізуватися тільки через суміжні види економічної діяльності (енергетичне машинобудування, сільськогосподарське машинобудування, обладнання і матеріали для функціонування житлово-комунального господарства) або через сферу послуг.

За даними Державної служби статистики [8] основними факторами, що стримували у 2016 році промислове виробництво,на думку самих виробників (табл.1),є недостатній попит і фінансові обмеження:

Таблиця 1

Фактори стримування розвитку промислового виробництва України у 2016 році (за результатами щоквартального опитування, усереднені)*

\begin{tabular}{|l|c|c|}
\hline \multicolumn{1}{|c|}{ Фактор } & $\begin{array}{c}\text { Доля підприємств, } \\
\text { що його визнають, } \\
\text { \% до опитаних }\end{array}$ & $\begin{array}{c}\text { Динаміка змін у } \\
\text { порівнянні з 2015 p., } \\
\text { «土\%» }\end{array}$ \\
\hline Недостатній попит & 47 & -3 \\
\hline Фінансові обмеження & 38 & -7 \\
\hline Нестача сировини, матеріалів, устаткування & 11 & -2 \\
\hline Нестача робочої сили & 5 & +2 \\
\hline Інші фактори обмеження & 27 & Без змін \\
\hline Нічого не стримує & 14 & +4 \\
\hline
\end{tabular}

*складена автором на підставі [8].

Систематизовані дані свідчать про усвідомлення за останні три роки (2014 - 2016 р.p.) підприємцями власної відповідальності за ведення підприємницької діяльності: суттєво зменшуються фінансові (на 15\%) і ринкові (на 6\%) обмеження, які підприємці визнають такими.

Порівняння отриманих результатів 3 даними авторського дослідження [9] при формуванні переліку основних ризиків діяльності промислових 
підприємств (табл. 2) станом на 2010 рік, свідчить, що зазначені у 2016 році обмеження можна вважати наслідком реалізації ризиків ліквідності і некоректного вибору сфери вкладання капіталу.

Таблиця 2

Перелік основних ризиків підприємницької діяльності в Україні, сформований шляхом опитування підприємців.

\begin{tabular}{|l|c|}
\hline \multicolumn{1}{|c|}{ Ризики підприємницької діяльності } & $\begin{array}{c}\text { Вагомість ризику,\% Для } \\
\text { промислових підприємств }\end{array}$ \\
\hline Ризик ліквідності & 32,0 \\
\hline Ризик некоректності вибору сфери вкладання капіталу & 26.4 \\
\hline Ризик підвищення заборгованості з боку постійних клієнтів & 21,1 \\
\hline Інфляційний ризик & 20,5 \\
\hline Виробничі ризики & незначний \\
\hline Ризик зміни пріоритетів клієнтів & незначний \\
\hline Ризик неплатоспроможності клієнта & незначний \\
\hline
\end{tabular}

*сформовано на підставі експертного опитування

Також дослідження показують, що управлінці різних данок, керівники промислових підприємств не передбачали стратегічних змін зовнішнього середовища в межах держави (виробничі ризики і ризики зміни пріоритетів клієнтів визнавалися як незначні).

Збільшення долі підприємств, які не мають стримувальних факторів вказує на вихід з ринку підприємств, які не витримують змін зовнішнього середовища (табл.3).

Таблиця 3

Кількість суб’єктів економіки за організаційними формами [8]*

\begin{tabular}{|l|c|c|}
\hline \multicolumn{1}{|c|}{ Вид економічної діяльності } & $\begin{array}{l}\text { Кількість/доля } \\
\text { зареєстрованих суб'єктів } \\
\text { на 1.01.2017, од./\% }\end{array}$ & $\begin{array}{l}\text { Кількість/доля } \\
\text { зареєстрованих суб'єктів } \\
\text { на 1.01.2014, од./\% }\end{array}$ \\
\hline Усього юридичних осіб & 1185071 од. / 100\% & 1369348 од. / 100\% \\
\hline $\begin{array}{l}\text { У т.ч. } \\
-\quad \text { приватне підприємство }\end{array}$ & $17,1 \%$ & $20,33 \%$ \\
\hline - державне підприєство & $0,34 \%$ & $0,43 \%$ \\
\hline - виробничий кооператив & $0,19 \%$ & $0,19 \%$ \\
\hline - обслуговуючий кооператив & $1,53 \%$ & $1,50 \%$ \\
\hline Інші організаційні форми & $80,84 \%$ & $77,55 \%$ \\
\hline
\end{tabular}

*складено автором за результатами статистичної обробки даних [8]. Обрано організаційні форми, які можуть займатися виробничою діяльністю.

Якщо на початку XXI століття вагомість промисловості у формуванні державного бюджету становила 66\%, а сфери послуг 34\% [9], то на кінець другого десятиліття стратегія формування надходжень змінюється $[7,8]$. Обсяг реалізованої продукції промислового призначення в середньому за 2016 p. становить $37 \%$ до всієї реалізованої продукції,споживчої продукції тривалого використання 0,9\% [8]. Змінюється і структура видів економічної діяльності в середині промисловості (табл.4). 

Таблиця 4

Порівняльна характеристика реалізації продукції промисловості*

\begin{tabular}{|l|c|c|}
\hline \multicolumn{1}{|c|}{ Вид економічної діяльності } & $\begin{array}{c}\text { Структура випуску } \\
\text { товарів та послуг за } \\
\text { ВЕД, } \\
\text { \% до загальної }\end{array}$ & $\begin{array}{c}\text { Структура випуску } \\
\text { товарів та послуг за } \\
\text { ВЕД, } \\
\text { кілько загальної } \\
\text { кількості у 2014 р. }\end{array}$ \\
\hline Загалом промисловість, у т.ч. & $10016 \mathrm{p}$. & 100 \\
- добувна & 13,1 & 12,9 \\
- переробна & 65,0 & 67,7 \\
-постачання електроенергії, пари, газу, повітря & 21,0 & 18,2 \\
\hline У т.ч. у переробній & & 3,4 \\
\hline - вироби з деревини та поліграфія & 3,5 & 3,9 \\
\hline - виробництво хімічної продукції & 3,3 & 7,9 \\
\hline - машинобудування & 6,5 & 3,2 \\
\hline - виробництво автотранспорту & 2,1 & \\
\hline
\end{tabular}

*складена автором на підставі даних [8]

Таким чином, основними показниками, що характеризуватимуть промисловість у 2017 році можна вважати:

- сталий розвиток,

- зменшення обсягів ринків прямої реалізації продукції,

- диверсифікація номенклатурних позицій,

- зменшення обсягів виробництва за номенклатурними позиціями,

- техніко-технологічні інновації в умовах обмеженого ресурсного забезпечення.

3 метою визначення напрямів оновлення, реконструкції і реставрації добувної і переробної промисловості в ході виконання дослідження було зроблено спробу систематизувати напрями диверсифікації і диференціації через суміжні види економічної діяльності (табл. 5).

Проведений аналіз можливостей засвідчив, що диверсифікація стає обов'язковим інструментом управління бізнес-процесами. I вже в межах усвідомлення свободи у прийнятті господарських рішень (табл.1) можлива диверсифікація товарного портфелю.

Таким чином, в ході виконання роботи було з'ясовано перспективи розвитку добувної і переробної промисловості України з урахуванням стратегічних їх пріоритетів.

3 урахуванням частоти прогнозного запиту того чи іншого напряму розвитку промисловості, було складено таблицю вагомості напрямів диверсифікації та диференціації (табл. 6). 
Таблиця 5

Прогнозні напрями диференціації і диверсифікації промисловості України*

\begin{tabular}{|c|c|c|c|c|c|c|c|}
\hline \multirow{3}{*}{$\begin{array}{c}\text { Вид економічної } \\
\text { діяльності }\end{array}$} & \multicolumn{7}{|c|}{ Стратегічні сфери розвитку України до 2020 року/ Можливості добувної і переробної промисловості } \\
\hline & \multicolumn{2}{|c|}{ інфраструктура } & \multirow[t]{2}{*}{ енергетика } & \multirow{2}{*}{$\begin{array}{c}\text { сільське } \\
\text { господарство та } \\
\text { рибальство } \\
\end{array}$} & \multirow{2}{*}{$\begin{array}{c}\text { житлово- } \\
\text { комунальне } \\
\text { господарство } \\
\end{array}$} & \multicolumn{2}{|c|}{ фактори національної гордості } \\
\hline & транспортна & $\begin{array}{c}\text { телекомунікаці } \\
\text { йна }\end{array}$ & & & & $\begin{array}{l}\text { космічна } \\
\text { галузь }\end{array}$ & $\begin{array}{c}\text { інноваційні } \\
\text { програми }\end{array}$ \\
\hline $\begin{array}{l}\text { Добувна } \\
\text { промисловість }\end{array}$ & $\begin{array}{c}\text { Розробка кар’єрів } \\
\text { на замовлення } \\
\text { автодору }\end{array}$ & - & $\begin{array}{c}\text { Добування } \\
\text { невідновлювальн } \\
\text { ої сировини }\end{array}$ & $\begin{array}{c}\text { Видобування } \\
\text { мінеральної } \\
\text { сировини для } \\
\text { хімічної } \\
\text { промисловості } \\
\text { (виробництво } \\
\text { добрив) } \\
\end{array}$ & $\begin{array}{c}\text { Розробка } \\
\text { кар'єрів для } \\
\text { видобутку } \\
\text { сировини }\end{array}$ & $\begin{array}{c}\text { Розробка } \\
\text { кар'єрів для } \\
\text { видобутку } \\
\text { сировини }\end{array}$ & - \\
\hline $\begin{array}{l}\text { Переробна } \\
\text { промисловість, у } \\
\text { т.ч. }\end{array}$ & & & & & & & \\
\hline $\begin{array}{lr}\text { вироби } & 3 \\
\text { деревини } & \text { та } \\
\text { поліграфія } & \end{array}$ & $\begin{array}{c}\text { Окремі елементи } \\
\text { оздоблення }\end{array}$ & - & $\begin{array}{c}\text { Альтернативні } \\
\text { види палива }\end{array}$ & $\begin{array}{c}\text { Матеріали для } \\
\text { мульчування } \\
\text { земель, } \\
\text { екологічні } \\
\text { матеріали для } \\
\text { будівництва, } \\
\text { елементи } \\
\text { оздоблення, } \\
\text { пакування. }\end{array}$ & $\begin{array}{c}\text { Елементи } \\
\text { конструкцій, } \\
\text { елементи } \\
\text { оздоблення }\end{array}$ & $\begin{array}{c}\text { Елементи } \\
\text { оздоблення }\end{array}$ & $\begin{array}{c}\text { Екологічні і } \\
\text { відновлювальні } \\
\text { технології } \\
\text { переробки }\end{array}$ \\
\hline $\begin{array}{l}\text { виробництво } \\
\text { хімічної } \\
\text { продукції }\end{array}$ & $\begin{array}{c}\text { Матеріали } \\
\text { конструкційні і } \\
\text { оздоблювальні, } \\
\text { матеріали для } \\
\text { автодору }\end{array}$ & Нові матеріали & $\begin{array}{c}\text { Тепло- i } \\
\text { енергоізоляційні } \\
\text { матеріали, } \\
\text { конструкційні } \\
\text { матеріали }\end{array}$ & $\begin{array}{c}\text { Хімічні засоби } \\
\text { захисту рослин і } \\
\text { тварин, добрива, } \\
\text { конструкційні } \\
\text { матеріали }\end{array}$ & $\begin{array}{c}\text { Конструкційні і } \\
\text { оздоблювальні } \\
\text { матеріали, } \\
\text { матеріали для } \\
\text { машинобудуванн } \\
\text { я } \\
\end{array}$ & $\begin{array}{l}\text { Конструкційні } \\
\text { i } \\
\text { оздоблювальні } \\
\text { матеріали }\end{array}$ & $\begin{array}{c}\text { Матеріали із } \\
\text { заданими } \\
\text { властивостями }\end{array}$ \\
\hline $\begin{array}{l}\text { машинобудуван- } \\
\text { ня }\end{array}$ & \multicolumn{4}{|c|}{ Машини та обладнання спеціального призначення } & \multicolumn{2}{|c|}{$\begin{array}{c}\text { Машини, обладнання, } \\
\text { устаткування спеціального } \\
\text { призначення }\end{array}$} & $\begin{array}{c}\text { Спеціалізоване } \\
\text { машинобудування, } \\
\text { мале } \\
\text { машинобудування }\end{array}$ \\
\hline $\begin{array}{l}\text { виробництво } \\
\text { автотранспорту }\end{array}$ & $\begin{array}{c}\text { спеціалізований і } \\
\text { пасажирський } \\
\text { транспорт }\end{array}$ & & & пеціалізоване і ма. & автомобілебудува & & \\
\hline
\end{tabular}

*складена автором на підставі аналізу зв'язків видів економічної діяльності 
Таблиця 6

Матриця вагомості перспективних напрямів розвитку промисловості*

\begin{tabular}{|c|c|}
\hline \multicolumn{1}{|c|}{ Напрям, перспективний запит } & Вагомість, $\%$ \\
\hline Добувна промисловість: & 100 \\
\hline - Розробка кар'єрів на замовлення & 60 \\
\hline - Добування невідновлювальної сировини паливно-енергетичної групи & 20 \\
\hline $\begin{array}{l}\text { Видобування мінеральної сировини для хімічної промисловості } \\
\text { (виробництво добрив) }\end{array}$ & 20 \\
\hline Переробна промисловість: & 100 \\
\hline - Машини, обладнання і устаткування спеціального призначення & 16,5 \\
\hline - Спеціалізоване і мале автомобілебудування & 16,5 \\
\hline - Матеріали конструкційні & 13,8 \\
\hline - Матеріали оздоблювальні і окремі елементи оздоблення & 8,4 \\
\hline - Матеріали із заданими властивостями & 8,4 \\
\hline - Елементи конструкцій & 2,8 \\
\hline - Спеціалізоване і мале машинобудування & 2,8 \\
\hline - Спеціалізований транспорт & 2,8 \\
\hline - Пасажирський транспорт & 2,8 \\
\hline - Матеріали для машинобудування & 2,8 \\
\hline - Тепло-і електроізоляційні матеріали & 2,8 \\
\hline - Матеріали для автодору & 2,8 \\
\hline - Хімічні засоби захисту рослин і тварин, хімічні добрива & 2,8 \\
\hline - Матеріали для мульчування земель & 2,8 \\
\hline - Екологічні і відновлювальні технології переробки & 2,8 \\
\hline - Альтернативні види палива & 2,8 \\
\hline - Екологічні матеріали для будівництва & 2,8 \\
\hline - Елементи пакування & \\
\hline
\end{tabular}

*складена автором на підставі статистичної обробки даних аналітичного дослідження.

Таким чином, великотоннажне масове виробництво втрачатиме і надалі перспективи розвитку, актуальним $\epsilon$ серійне i iндивідуальне одиничне виробництво. Такий підхід до формування засад діяльності промисловості («важкої промисловості») вимагає повного переоснащення i оновлення потужностей.

За даними [10] інноваційно активними в Україні є 16\% підприємств. Ця цифра корелює $з$ долею підприємств, які не відчувають жодних обмежень у власній діяльності (14\%, табл.1). 3 придбаних підприємствами технологій 54\% з устаткуванням, 9\% - тільки права власності, 1\% - придбання технологічного комплексу зі спеціалістами[11].Як свідчать розрахунки, мінімум 84\% підприємств України потребують зміни бізнес-процесів і запропонована матриця вагомості інновацій може стати першим кроком у структуризації стратегї̈ сталого розвитку промислового підприємства.

Аналіз матриці вагомості перспективних напрямів розвитку промисловості свідчить, що розробка кар'єрів на замовлення виводить 3 
інерційного руху цінові потоки на первинну сировину і робить цей вид діяльності привабливим. Оскільки надання дозволів на розробку кар'єрів $\epsilon$ функцією місцевої влади, то їх ціна може постійно зростати 3 розвитком технологічних можливостей.

Як видно 3 результатів дослідження (табл. 2), промисловці недооцінювали ризики зміни пріоритетів клієнтів внаслідок зміни умов зовнішнього середовища, що i призводить до наявного протиставлення стратегії розвитку України і напрямів бажаного розвитку самих промислових підприємств.

Висновки. В ході виконання дослідження було показано, що стратегія розвитку держави входить у протиріччя 3 усвідомленими ризиками промисловців України. Фондоємна промисловість втрачає перспективи функціонування внаслідок відсутності інформаційного аналізу i систематизації.

Аналіз напрямі розвитку України показав, що такі види економічної діяльності як добувна промисловість та розроблення кар'єрів, переробна промисловість (у тому числі поліграфія, хімічна промисловість, виробництво машин i устаткування), будівництво мають перспективи розвитку через суміжні види економічної діяльності (енергетичне машинобудування, сільськогосподарське машинобудування, обладнання i матеріали для функціонування житлово-комунального господарства) або через сферу послуг.

Інноваційно актуальними напрямами оновлення, реконструкції i реставрації техніко-технологічної бази конкретних промислових підприємств стають гнучкі технології, багатофункціональне обладнання i мобільні (пересувні) технологічні лінії. Таким чином, набуває змістовного наповнення дефініція інноваційної реконструкції промислових підприємств. Застосування таких інструментів економіки сталого розвитку, як синтез, передбачення, співставлення, формування очікувань дозволяє генерувати нові можливості для добувної і переробної промисловості України.

В ході виконання роботи сформована структура сучасних показників, що характеризують сферу виробничої діяльності промислових підприємств(таких як машинобудування, хімічна промисловість, енеговиробництво) визначено актуальні можливі інновацій та перспективи їх реалізації. Сформований рейтинг інновацій для промислового виробництва, що є одночасно переліком сфер інвестування та перспективного розвитку.

Недостатність професійно підготованих кадрів 3 досвідом перенавчання і комплексного навчання $\epsilon$ стримуючим фактором розвитку промисловості і вимагає сталих соціальних інновацій.

Наукова новизна роботи полягає у визначенні перспектив розвитку добувної та переробної промисловості через суміжні види економічної 
діяльності, формуванні структури показників виду економічної діяльності та матриці вагомості напрямів диференціації $\mathrm{i}$ диверсифікації переробної промисловості з визначенням можливих інновацій та перспектив їх реалізації. Теоретичне значення роботи розкривається у послідовності кроків застосування методології Форсайту для визначення перспектив добувної i переробної промисловості України в умовах сталого розвитку при реалізації стратегії «Україна - 2020».

Отримані результати є першим кроком аналітичної роботи 3 метою визначення перспектив вітчизняної промисловості на засадах економіки сталого розвитку. Можуть бути застосовані при формуванні стратегій бізнесуправління промисловими підприємствами.

\section{Література:}

1. Мунтиян В.И. Вызов системному кризису - инновационная модель экономики. В.И. Мунтиян// Економічний вісник НТУУ «КПІ», - К.: НТУУ «КПІ» ВПІ ВПК «Політехніка», 2012, - №9, - 520с. - С.35-41.

2. Шестаков А.Л. Проблемы российских предприятий, подходы к их решению, причины проблем /А.Л. Шестаков // РИА «Стандариты и качество», 2002-2009 [Електронний pecypc]. - Режим доступу: http://quality.eup.ru/MATERIALY2/problems.html.

3. Базилевич В. Д. Неортодоксальна теорія Й. А. Шумпетера. В.Д. Базилевич // Історія економічних учень: У 2 ч.. - 3-е видання. - К.: Знання, 2006. - Т. 2. - С. 312324. $-575 \mathrm{c}$.

4. Згуровський М.3. Розробка методики визначення загроз сталому економічному розвитку України / М.З. Згуровський, О.А. Гавриш, С.В. Войтко // Економічний вісник НТУУ «КПІ», - К.: ТОВ ВД «ЕКМО», 2011. - №8 - С. 26-33.

5. Гавриш О.А. Проблеми сталого розвитку національної економіки. О.А. Гавриш, С.В. Войтко// Економічний вісник НТУУ «КПІ», - К.: НТУУ «КПІ» ВПІ ВПК «Політехніка», 2012, - №9, - 520c. - С.10-15

6. Кологривов Я.І. Теоретичні засади використання методології Форсайту у передбаченні розвитку промислових підприємств / Я.І Кологривов // Економічний вісник НТУУ «КПІ». - 2015. - № 12 (2015). - [Електронний ресурс]. - Режим доступу: http://ev.fmm.kpi.ua/article/view/44234

7. Про стратегію сталого розвитку «Україна - 2020». Указ Президента України, № 5/2015, $\begin{array}{lllll}\text { від 12.01.2015 [Електронний } & \text { ресурс]. }\end{array}$ доступу:http://zakon4.rada.gov.ua/laws/show/5/2015

8. Державна служба статистики України[Електронний ресурс]. - Режим доступу: http://www.ukrstat.gov.ua/

9. Підлісна О.А. Основи виробничого підприємництва: навч. посіб. / О.А. Підлісна, В.В. Янковий, М.П. Дорошенко та ін.; за ред. О.А. Підлісної та В.В. Янкового. - К.: НТУУ «КПІ», 2010. $-272 \mathrm{c}$

10. Голей Ю. М. Стан та проблеми інноваційного розвитку промислових підприємств України / Ю. М. Голей // Вісник Дніпропетровського університету. Серія : Менеджмент інновацій. - 2015. - Т. 23. - Вип. 4. - С. 35-42.

11. Наукова та інноваційна діяльність в Україні, 2014: стат. зб. [Електронний ресурс]. Режим доступу: http://www.ukrstat.gov.ua. 